\title{
Immunohistochemical and Histopathological Study of Anaplastic Lymphoma Kinase and Tyrosine-kinase Receptor Expression in Bronchogenic Carcinoma
}

\author{
Ahmed Fawzy ${ }^{1 *}$, Samira Mahmoud Abd Allah ${ }^{2}$, Moustafa Mohammed Samy ${ }^{2}$, Lobna Omar Al Farouk ${ }^{2}$ \\ ${ }^{1}$ Department of Specialist of Pathology, Egyptian Armed Forces Hospitals, Haram, Giza, Egypt; ${ }^{2}$ Department of Pathology, \\ Faculty of Medicine, Cairo University, Giza, Egypt
}

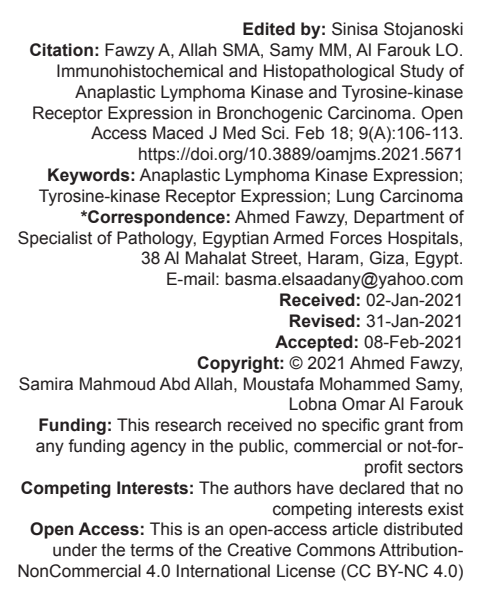

\begin{abstract}
BACKGROUND: Adenocarcinoma of the lung is the most common tumor type of primary lung cancer and is characterized by heterogeneity on the molecular, clinical, and pathological levels. The presence of an anaplastic lymphoma kinase (ALK) fusion oncogene defines a molecular subset of non-small cell lung cancer with distinct clinical and pathologic features. Furthermore, the tyrosine-kinase receptor (C-kit) is considered to be expressed in various solid tumors, including carcinomas of the lung.

AIM: This study aims to correlate immunohistochemical (IHC) expression of ALK and C-kit with pathological features of lung carcinoma and to correlate IHC expression of ALK with IHC expression of C-kit in lung carcinoma.

MATERIALS AND METHODS: The material of this study consists of paraffin blocks of 60 cases of patients with bronchogenic carcinoma, IHC staining with ALK and C-kit then analysis of immunoreactivity scoring was done.

RESULTS: As regards ALK expression, 3 (5\%) cases showed positive expression of ALK and 57 (95\%) cases showed negative expression of ALK with no statistically significant correlation between the ALK expression and the histopathological type. While C-kit expression, $4(6.7 \%)$ cases showed positive expression and $56(93.3 \%)$ cases showed negative expression of C-kit with statistically significant correlation between the C-kit expression and the histopathological type.
\end{abstract}

CONCLUSION: There is an association between expression of c-kit and tumor histological type in lung carcinoma. Expression was notably significant among adenocarcinomas and small cell carcinomas.

\section{Introduction}

Adenocarcinoma of the lung is the most common histological type of primary lung cancer [1] and is a heterogenous tumor with diverse molecular, clinical, and pathological characteristics. Identification of molecular driver mutations and their therapeutic implications in lung adenocarcinoma have become an important area of research as evidenced by the abundance of genomic and mutational studies [2].

Rearrangements of the anaplastic lymphoma kinase (ALK) gene drive the malignant phenotype in $3-7 \%$ of primary lung adenocarcinomas [3]. The resulting fusion protein, most often a fusion with echinoderm microtubule-associated protein-like 4 (EML4), has a constitutively active tyrosine kinase domain. The small molecule drug crizotinib is a specific inhibitor of this kinase [4], and cases with the rearrangement respond to crizotinib treatment [5]. Therefore, accurate, rapid, and inexpensive identification of tumors growing under the influence of translocated ALK is needed [6].
Several studies have investigated the predictive value of pathological and morphological features in detecting ALK- rearranged tumors; however, the results of these studies have been inconsistent because of the limited number of ALK-rearranged tumors [3], [7]. Solid signet ring cell subtypes and cribriform pattern have been associated with ALK rearrangement in lung adenocarcinoma [7]. However, the comparative analysis of these histomorphological features and subtypes of ALK-rearranged lung adenocarcinoma based on driver oncogene mutations has not been clearly established in lung adenocarcinoma [8].

Small cell carcinoma can occur in any organ, but the great majority develops in the lung. Small cell lung carcinoma (SCLC) shows aggressive behavior and good prognosis. Some studies of SCLC have shown that kit protein is expressed in $30-100 \%$ of SCLC [9]. The difference of the percentage may be due to different primary antibodies used, staining methods, incubation periods, and interpretation of the immunostaining. In addition, one report showed that a few kit gene mutations were present in SCLC, but others did not [10]. 
Kit gene, mapped to $4 \mathrm{q} 12$, encodes tyrosine kinase receptor (C-kit) oncoprotein called kit (CD117). This molecule is transmembranous oncoprotein involved in tumorigenesis of some neoplasms including gastrointestinal stromal tumor, acute myeloid leukemia, mast cell neoplasms, germ cell tumors, melanoma, neuroendocrine carcinomas, large cell neuroendocrine carcinoma, and SCLC. The host spots of gene mutations are exons $9,11,13$, and 17 of kit gene [11].

SCLC constitutes approximately $15 \%$ of all cases of primary lung cancer (Govindan et al.; 2006). SCLC is sensitive to chemotherapy and radiotherapy, but long-term survival is low and the majority of patients eventually develop progressive disease. There is a high rate of relapse even among patients who achieve a complete response. High levels of expression of C-kit and its ligand, stem cell factor, have been widely found in both SCLC tumors and established cell cultures [12].

\section{Materials and Methods}

\section{Case selection}

\section{Ethical consideration}

The protocol of the study was approved by the Ethical Committee of Faculty of Medicine, Cairo University (as the study performed on Archived blocks no informed consent needed).

The material of this study consists of paraffin blocks of sixty cases of patients with bronchogenic carcinoma, collected to private labs where the copies of their pathology reports were available at computer data base (From January 2016 to December 2017).

The specimens were obtained by either bronchoscopic biopsies, transbronchial lung biopsy, computed tomography guided core biopsy, tru-cut biopsy, or fiberoptic biopsy.

The data collected from the pathology request sheets enclosed with specimens included: Ages of all patients at diagnosis, sex, tumor subtypes, and grading.

\section{Inclusion criteria}

The following criteria were included in the study:

1. Cases of primary lung carcinomas with available clinic-pathological data

2. Specimens with adequate tumor tissue

Specimens with good histological orientation.

\section{Exclusion criteria}

The following criteria were excluded from the study:
1.

Cases of primary lung carcinomas without available clinicopathological data

2. Cases with lost files or unavailable blocks.

Specimens with inadequate tumor tissue.

\section{Steps of the work}

Three sections (4 microns thick) were prepared from each paraffin block was re-cut by rotatory microtome, one of them was stained with hematoxylin and eosin for histopathological evaluation (for grading), and the other two were mounted on poly-L-Lysine-coated slides (Superfrost slides) and subjected to two immunohistochemical (IHC) markers: ALK and C-kit. All slides were examined under light microscope. Finally, IHC automated staining for each case was conducted for both ALK and C-kit, for evaluation as described in details late.

\section{Immunohistochemical staining for ALK and C-kit}

The sections were deparaffinized in xylene, then were hydrated through a series of graded alcohols (95-70\%), distilled water, and phosphate buffered saline (at $\mathrm{pH} 7.5$ ). The slides were then immersed in citrate buffer $(\mathrm{pH} 6)$ and were pretreated by microwave oven $800 \mathrm{w}$ for $20 \mathrm{~min}$ for antigen retrieval. After a 25-min cooling period, the endogenous peroxidase activity was inhibited by incubation in 3\% hydrogen peroxide $\left(\mathrm{H}_{2} \mathrm{O}_{2}\right)$ for $5 \mathrm{~min}$. After washing with Tris-buffered saline, the sections were incubated with the primary antibody for $1 \mathrm{~h}$ at room temperature. The primary antibodies are rabbit polyclonal antibodies (61-0028-2 Genemed) and (NBP1-85707, Novus Biologicals), diluted at 1:100 in primary antibody diluent (Genemed).

The sections were washed in Tris-buffer and incubated with avidin-biotin-peroxidase system for 30 min. Peroxidase reaction was detected by addition of diaminobenzidine tetrahydrochloride. All slides were rinsed well in tap water for 5 min then slightly counterstained with hematoxylin for 1-2 $\mathrm{min}$ and dehydrated in ascending alcohol. The slides were cleared in xylene for 3 changes, and then Canada balsam and cover slips were applied.

C-kit antibody labels breast epithelium, skin basal cells (melanocytes), spermatocytes, oocytes, and tissue mast cells. This antibody labeled $89 \%$ of seminomas (dysgerminomas), and $36 \%$ of small cell carcinomas of the lung [13].

The positive control for cases stained for ALK was normal small intestine ( $T$ cells), while the positive staining (normal) for C-kit was breast epithelium.

\section{Evaluation of $A L K$ and C-kit expression}

All sections were screened to disclose the areas with well-preserved tissue architecture and cell morphology for scoring of immunoreactivities. 
Areas with deterioration of tissue morphology due to processing were discarded in the analysis.

For the ALK stains, only cytoplasmic staining was considered as a positive reaction. The number of immunopositivity cells was semiquantitative estimated: No positive cells $(-) ;<50 \%$ of the tumor cells staining positive $(+) ; 50-75 \%$ of tumor cells staining positive (++); and $>75 \%$ of tumor cells staining positive $(+++)$. The staining intensity was graded on a scale from 0 to $3+(0$, negative; 1+, weak; 2+, moderate; 3+, intense) [14].

Staining of C-kit expression of tumors was scored as negative (0) if $<5 \%$ of cells were positive, weak staining $(+)$ if $5-25 \%$ of cells were positive, moderate $(++)$ if $26-50 \%$ of cells were positive, and strong $(+++)$ if $>50 \%$ of cells were positive [15].

\section{Statistical analysis}

Computer software package Statistical Package for Social Sciences versus 21 was used in the analysis to estimate the correlation between ALK and C-kit immunoreactivity and clinic-pathological data for all cases (age, gender, histological type, and grade).

The significance of the results was assessed by determining the probability factor " $p$ " value using Chi-square test. $p<0.05$ was considered statistically significant.

\section{Results}

\section{Description of the study variables}

This retrospective study was conducted on 60 cases of bronchogenic carcinoma. Their ages ranged from 26 to 85 years with mean age 59.18 years.

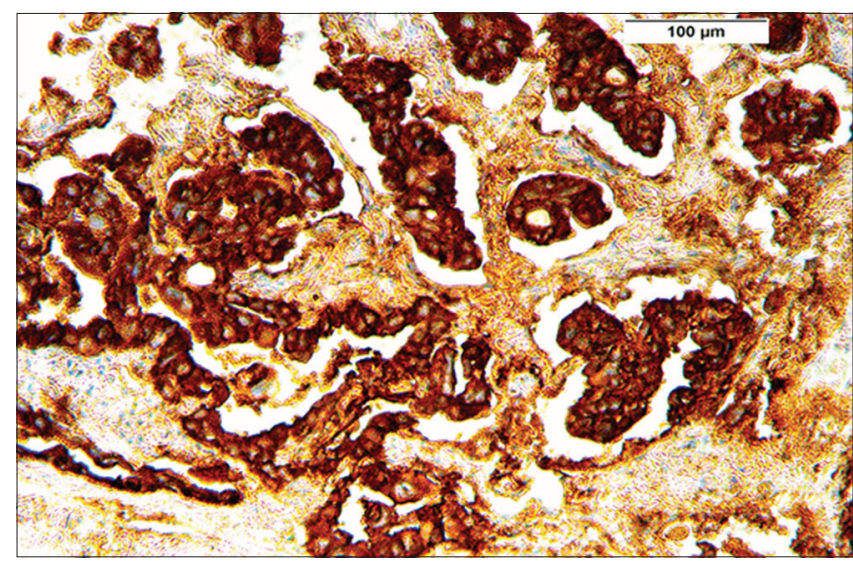

Figure 1: Moderately differentiated adenocarcinoma grade II, with strong cytoplasmic staining for anaplastic lymphoma kinase (score 3+) (200x)

As regards the histological type of lung cancer, $44(73.3 \%)$ cases were classified as adenocarcinoma, $14(23.3 \%)$ cases were classified as small cell carcinoma, and one case $(1.7 \%)$ was adenosquamous
Table 1: The pathological data of the collected cases

\begin{tabular}{ll}
\hline Parameter & Number (\%) \\
\hline Sex & \\
Female & $16(26.7)$ \\
Male & $44(73.3)$ \\
Histological type & \\
Adenocarcinoma & $44(73.3)$ \\
Small cell carcinoma & $14(23.3)$ \\
Squamous cell carcinoma & $1(1.7)$ \\
Adenosquamous carcinoma & $1(1.7)$ \\
Grades of differentiation & $28(46.7)$ \\
G2 & $18(30)$ \\
G3 & $14(23.3)$ \\
Undifferentiated & \\
\hline
\end{tabular}

carcinoma and other one case $(1.7 \%)$ was squamous cell carcinoma.

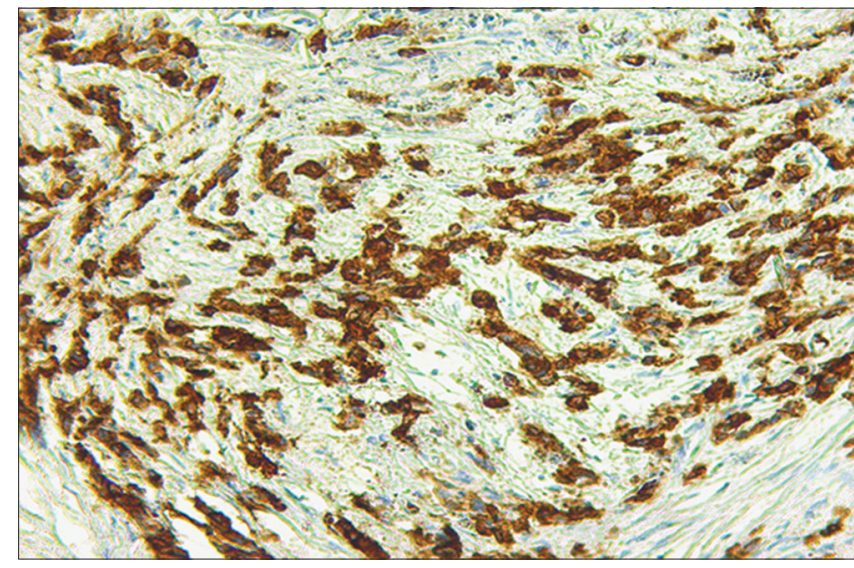

Figure 2: Poorly differentiated adenocarcinoma grade III, with strong cytoplasmic staining for anaplastic lymphoma kinase (score 3+) (200x)

As regard sex distribution $44(73.7 \%)$ were males and $16(26.3 \%)$ were females. As regard sex distribution among lung adenocarcinomas, 28 (63.6\%) were males and 16 (36.4\%) were females.

As regards the histological grades, most of the case which constitute 28 cases $(46.7 \%)$ were moderately differentiated, while the rest of the cases were distributed between poorly differentiated and undifferentiated constituting $18(30 \%)$ and $14(23.3 \%)$, respectively. The pathological data of the cases are summarized in Table 1.

As regards ALK expression, $3(5 \%)$ cases showed positive expression of ALK and 57 (95\%) cases showed negative expression of ALK (Figures 1-3).

\section{Correlation between variables among the} study group

Concerning ALK expression in non-SCLC (NSCLC), only $6.5 \%$ of cases showed positive expression of ALK.

Concerning ALK expression in lung adenocarcinomas, only $6.8 \%$ of lung adenocarcinomas showed positive expression of ALK. Correlation between the ALK expression and histopathologic type among the study group showed a statistically nonsignificant correlation $(p=0.76)$.

Correlation between the tumor histological grade and expression of ALK among the study group 


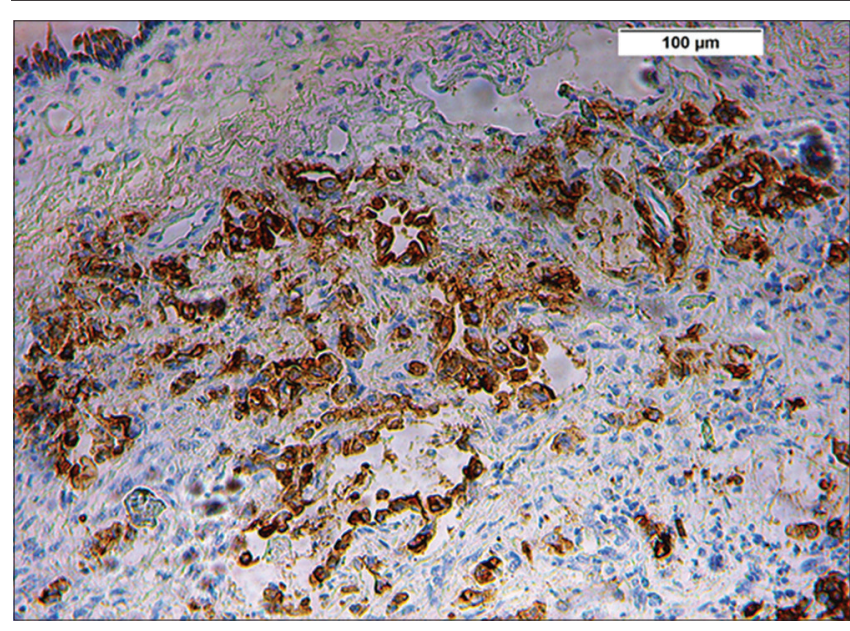

Figure 3: Poorly differentiated adenocarcinoma grade III showed moderate cytoplasmic staining for anaplastic lymphoma kinase (score 2+) (200x)

showed three positive cases and distributed as two cases were moderately differentiated, one case was poorly differentiated, no well differentiated, or undifferentiated cases. The correlation was statistically not significant $(p=0.601)$.

As regard ALK scoring, two of the positive cases showed cell positivity $>75 \%$ (score 3 ) and the other positive one showed positive cells ranged between $50 \%$ and $75 \%$ (score 2). Their correlation with NSCLC and SCLC was statistically not significant $(p=0.618)$.

Similarly, the correlation between ALK scoring and the different histologic types was statistically not significant $(p=0.979)$.

As regards C-kit expression, $4(6.7 \%)$ cases showed positive expression and 56 (93.3\%) cases showed negative expression of C-kit (Figures 4).

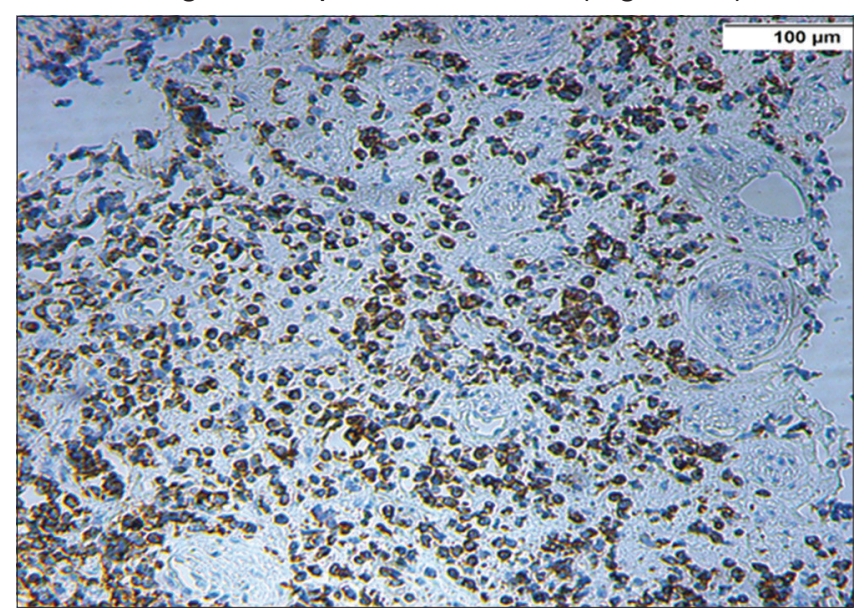

Figure 4: Small cell carcinoma, undifferentiated showed strong cytoplasmic staining for tyrosine-kinase receptor (200x)

Expression of C-kit was statistically significant among small cell carcinoma. Both cases of adenocarcinoma and squamous cell carcinoma were negative for C-kit. Correlation between the tumor histological type and expression of C-kit among the study group showed a statistically significant correlation $(p<0.003)$.
Correlation between the tumor histological grade and expression of C-kit among the study group showed that the four positive cases for C-kit were small cell carcinoma which was by their name considered as undifferentiated carcinoma and no well, moderate. or poor differentiated cases. The correlation was statistically significant ( $p=0.001)$. All data regarding the correlation parameters of ALK and C-kit were summarized in Table 2.

Table 2: Correlation between expression of ALK and C-kit clinicopathological

\begin{tabular}{|c|c|c|c|c|c|c|}
\hline $\begin{array}{l}\text { Histopathological type } \\
\text { and grade }\end{array}$ & $\begin{array}{l}\text { ALK +ve } \\
(\%)\end{array}$ & $\begin{array}{l}\text { ALK -ve } \\
(\%)\end{array}$ & $\mathrm{p}$-value & $\begin{array}{l}\text { C-kit +ve } \\
(\%)\end{array}$ & $\begin{array}{l}\text { C-kit -ve } \\
(\%)\end{array}$ & $p$-value \\
\hline \multicolumn{7}{|c|}{ Histological type } \\
\hline Small cell carcinoma & $0(0)$ & $14(100)$ & $<0.76$ & $4(28.6)$ & $10(71.4)$ & $<0.003$ \\
\hline Adenocarcinoma & $3(6.8)$ & $41(93.2)$ & & $0(0)$ & $44(100)$ & \\
\hline Others & $0(0)$ & $2(100)$ & & $0(0)$ & $2(100)$ & \\
\hline \multicolumn{7}{|l|}{ Histological grade } \\
\hline G2 & $2(7.1)$ & $26(92.2)$ & 0.601 & $0(0)$ & $28(100)$ & 0.001 \\
\hline G3 & $1(5.6)$ & $17(94.4)$ & & $0(0)$ & $18(100)$ & \\
\hline Undifferentiated & $0(0)$ & $14(100)$ & & $4(28.6)$ & $10(71.4)$ & \\
\hline
\end{tabular}

As regard C-kit scoring, two of the four positive cases showed cell positivity $>50 \%$ (score 3 ). The other two were equally distributed between score 1 and 2 . The correlation was statistically not significant $(p=0.119)$.

\section{Discussion}

Adenocarcinoma of the lung is the most common histological type of primary lung cancer [1] and is a heterogenous tumor with diverse molecular, clinical, and pathological characteristics. Identification of molecular driver mutations and their therapeutic applications in lung adenocarcinoma has become an important area of research as evidenced by the abundance of genomic and mutational studies [2].

Although the EML4-ALK fusion gene is minor genetic abnormality in NSCLC [7], the incidence of lung cancer is increasing in many countries, the absolute number of lung cancer patients harboring the EML4ALK fusion gene is not trivial [16].

The present study demonstrated that cytoplasmic expression of ALK was significantly among lung adenocarcinomas. All cases of small cell carcinoma were negative for ALK. However, no significant correlations were regarded with tumor grade.

In our study, as regard sex distribution among lung adenocarcinomas, 28 (63.6\%) were males and 16 $(36.4 \%)$ were females. Indeed, in one study addressing lung adenocarcinomas, an imbalanced sex ratio was detected, with women exhibiting a 2.2-fold relative risk for an alteration [17], while in another study, there was a nearly balanced sex ratio [18].

In our study, as regards the histopathological type of bronchogenic carcinomas, $73.3 \%$ of cases 
were classified as adenocarcinomas. Similar finding was obtained by Martinez et al., 2013 and found that three-fourth of the cases were classified as adenocarcinoma [18].

Inthe presentstudy, we described an association between expression of ALK and lung adenocarcinomas. 3 out of 44 cases of lung adenocarcinomas were positive for ALK, while 4 out of 14 cases of small cell carcinoma showed C-kit expression.

Concerning ALK expression in NSCLC, in our study, only $6.5 \%$ of cases showed positive expression of ALK. ALK protein was expressed in $10.7 \%$ of 262 NSCLC tumors [19]. Paik et al., 2011 reported an association between expression of ALK and nonsmall cell carcinomas in $8.6 \%$ of 465 cases [20]. $5.1 \%$ of 99 cases were ALK positive [18]. IHC-positive results were demonstrated in $4.6 \%$ of 3244 cases [17]. ALK protein expression was detected in $4.2 \%$ of 473 cases [16]. ALK was detectable by IHC in $4 \%$ of 46 NSCLC specimens [21], 3.4\% of 523 cases were ALK (+) by IHC [22], $2.9 \%$ of 377 cases were positive by IHC [23]. Selinger et al., 2013, identified an ALK gene rearrangement in $1 \%$ of 594 cases, although the intensity of staining was weak in some cases [24]. $\mathrm{IHC}$ is a reliable screening tool for identification of ALK rearrangement in NSCLC and is antibody dependent.

Concerning ALK expression in lung adenocarcinomas, in our study, only $6.8 \%$ of lung adenocarcinomas showed positive expression of ALK. Similar finding was obtained by To et al., 2013, who found ALK expression in $5.9 \%$ of cases [25]. A slightly higher percentage was also obtained by Zhou et al., 2014 in a large series of cases of lung adenocarcinomas that showed a significant correlation with the ALK expression $(8.4 \%)$ [26]. Different findings were reported by Boland et al., 2009 [27], Takeuchi et al., 2009 [28], Jokoji et al., 2010 [29], Sakai et al., 2013 [30], Ying et al., 2013 [31], Han et al., 2013 [32], Zhou et al., 2014 [26], and Wang et al., 2014 [33]. IHC might provide a reliable and costeffective diagnostic approach in routine pathologic laboratories for the identification of suitable candidates for ALK-targeted therapy.

Sample selection (histological type and tumor grade), number of cases analyzed, and differences in staining evaluation may be held responsible for the observed discrepancies between different studies.

Concerning scoring of ALK expression in NSCLC, in our study, only two cases $(4.3 \%)$ of $\mathrm{IHC}$ NSCLCs showed an intense staining $(3+)$ while the remaining one case $(2.2 \%)$ showed a moderate staining $(2+)$, the present work supports a previous study by Paik et al., 2011 [20], in which ALK protein expression was consisting of IHC scores of $1+(3 \%)$, $2+(2.1 \%)$, and $3+(3.4 \%)$. Similar results were observed by Park et al., 2012 [19], who had observed that NSCLC patients with IHC score of $3(3.4 \%)$, score of $2(4.2 \%)$, and score of $1(1.9 \%)$. Moreover, in another study on lung cancer, cases of NSCLC were assessed as $1+$ (faint cytoplasmic staining, 21\%), 2+ (moderate, smooth cytoplasmic staining; $3 \%$ ), or $3+$ (intense, granular cytoplasmic staining in $\geq 10 \%$ of tumor cells; $8 \%$ ) [14]. Based on these findings, the IHC assay reliably detected NSCLC with ALK and may be useful as a screening method to identify these tumors.

Results of present study as regards correlation between scoring expression of ALK and lung adenocarcinomas support a previous study by Zhou et al. 2014, who found an association between scoring expression of ALK and lung adenocarcinomas [26]. Other study has observed a correlation between scoring expression of ALK and lung adenocarcinomas [34].

One report on lung adenocarcinomas showed $5.9 \%$ of ALK-positive tumor cells demonstrated strong and diffused granular staining in the cytoplasm [25]. In another studies, they also found similar results for cytoplasmic staining (7\%) [26], which was similar to our results $(6.8 \%)$. However, other studies on lung adenocarcinomas had found similar findings (6.1\%) [34]. These results suggest a possible role for IHC screening to be the first step in ALK testing algorithms, which can maximize the detection percentage of ALK positive case.

Small cell carcinoma can occur in any organ, but the great majority develops in the lung. SCLC shows aggressive behavior and poor prognosis [9]. SCLC constitutes approximately $15 \%$ of all cases of primary lung cancer [35].

Studies have confirmed that protein over expression or mutations of KIT are involved in growth and development of a variety of cancers. However, little is known about data of gene mutation and protein expression in SCLC patients [36].

The present study demonstrated that expression of C-kit was significantly associated with tumor histological type. Expression was notably significant among small cell carcinoma. All cases of non-small cell carcinoma were negative for C-kit. However, no significant correlations were regarded with tumor grade.

Many studies have reported that C-kit expression was related to SCLC [37], [38], [39], [40], [41], [42], [43]. KIT protein is expressed in a high percentage of SCLC tumors.

One study on lung cancer [40] failed to find a correlation between expression of C-kit and non-small cell cancer, which was similar to our study. Results of C-kit expressions were not so effective in whole histologically grouped patients.

In our study, concerning gender in lung small cell carcinoma, male gender was exclusive $(100 \%)$. Several authors suggested a possible role for predilection of male gender in small cell carcinoma (56.6\%) [37].

Our study stated that there is an scoring of expression of C-kit in $28.4 \%$ of SCLC; $14.2 \%$ showed 
strong staining, $7.1 \%$ were moderate positive, and $7.1 \%$ were weak positive, whereas $(71.4 \%)$ were negative. Burger et al., 2003 stated that the expression of C-kit, estimated by IHC, was demonstrated in $64 \%$ of SCLC samples; $41 \%$ showed moderate to strong staining and $23 \%$ were weakly positive, whereas (36\%) were negative [38]. The expression of KIT had no significant impact on survival.

Sample selection (histological type and tumor grade), number of cases analyzed and differences in staining evaluation, genetic and geographic variations may individually or in combination be held responsible for the observed discrepancies between different studies.

\section{Recommendation of the Study}

Although, it was recommended that IHC testing is clearly at least useful in routine practice as a screening test. The danger of missing treatable cases using this method (i.e., fluorescence in situ hybridization-positive, IHC-negative, and crizotinibsensitive tumors), especially when specimens contain adequate material. Thus, further investigations such as re-biopsy and repeated IHC may be helpful. The accurate and timely identification of patients with ALK-rearranged lung adenocarcinomas is likely to be of therapeutic importance. We believe that $\mathrm{IHC}$ is a preferred method for identifying ALK-rearranged lung adenocarcinomas in routine clinical practice.

\section{Ethical Approval}

The protocol of the study was approved by the Ethical Committee of Faculty of Medicine - Cairo University.

\section{References}

1. Devesa, SS, Bray F, Vizcaino AP, Parkin DM. International lung cancer trends by histologic type; male: Female differences diminishing and adenoca1cinoma rates rising. Int $\mathrm{J}$ Cancer. 2005;117(2):294-9. https://doi.org/10.1002/ijc.21183 PMid:15900604

2. Weir BA, Woo MS, Getz G, Perner S, Ding L, Beroukhim R, et al. Characterizing the cancer genome in lung adenocarcinoma. Nature. 2007;450(7171):893-8.

PMid: 17982442

3. Inamura $\mathrm{K}$, Takeuchi $\mathrm{K}$, Togashi $\mathrm{Y}$, Hatano $\mathrm{S}$, Ninomiya $\mathrm{H}$, Motoi N, et al. EML4-ALK lung cancers are characterized by rare other mutations, a TTF- 1 cell lineage, an acinar histology, and young onset. Mod Pathol. 2009;22(4):508-15. https://doi. org/10.1038/modpathol.2009.2

PMid: 19234440

4. McDermott U, lafrate AJ, Gray NS, Shioda T, Classon M, Maheswaran S, et al. Genomic alterations of anaplastic lymphoma kinase may sensitize tumors to anaplastic lymhoma kinase inhibitors. Cancer Res. 2008;68(9):3389-95. https://doi. org/10.1158/0008-5472.can-07-6186

PMid:18451166

5. Kwak EL, Bang YJ, Camidge DR, Shaw AT, Solomon B, Maki RG, et al. Anaplastic lymphoma kinase inhibition in nonsmall-cell lung cancer. N Engl J Med. 2010;363(18):1693-703. https://doi.org/10.1517/14728222.2011.550880 PMid:20979469

6. Le Quesne J, Maurya M, Yancheva SG, O'Brien M, Popat S, Wotherspoon AC, et al. A comparison of immunohistochemical assays and FISH in detecting the Alk translocation in diagnotic histological and cytological lung tumor material. J Thorac Oncol. 2014;9(6):769-74. https://doi.org/10.1097/ jto.0000000000000157

PMid:24787965

7. Rodig SJ, Mino-Kenudson M, Dacic S, Yeap BY, Shaw A, Barletta JA, et al. Unique clinicopathologic features characterize ALK-rearranged lung adenocarcinoma in the Western population. Clin Cancer Res. 2009;15(16):5216-23. https://doi. org/10.1158/1078-0432.ccr-09-0802

PMid:19671850

8. Kim H, Jang SJ, Chung DH, Yoo SB, Sun P, Jin Y, et al. A comprehensive comparative analysis of the histomorphological features of Alk-rearranged lung adenocarcinoma based on driver oncogene mutations: Frequent expression of epithelialmesenchymal transition markers than other genotype. PLoS One. 2013;8(10):e76999. https://doi.org/10.1371/journal. pone.0076999

PMid:24194854

9. LaPoint RJ, Bourne PA, Wang HL, Xu H. Co expression of c-kit and bcl-2 in small cell carcinoma and large cell neuroendocrine carcinoma of the lung. Appl Immunohistochem Mol Morphol. 2007;15(4):401-6. https://doi.org/10.1097/01. pai.0000213153.41440.7d

PMid:18091382

10. Mojica WD, Saena R, Starostik P, Cheney RT. CD117+ small cell lung cancer lacks the asp 816--val point mutation in exon 17. Histopathology. 2005;47(5):517-22. https://doi. org/10.1111/j.1365-2559.2005.02259.x PMid: 16242000

11. Hirota S, Isozaki K. Pathology of gastrointestinal stromal tumor. Pathol Int. 2006;56(1):1-9.

PMid: 16398673

12. Rygaard K, Nakamura T, Spang-Thomsen M. Expression of the proto-oncogenes c-met and c-kit and their ligands, hepatocyte growth factor/scatter factor and stem cell factor, in sclc cell lines and xenografts. Brit J Cancer. 1993;67(1):37-46. https://doi. org/10.1038/bjc.1993.7

PMid:7678980

13. Tsuura $Y$, Hiraki $H$, Watanabe $K$, Igarashi $S$, Shimamura $K$, Fukuda T, et al. Preferential localisation of c-kit product in tissue mast cells, basal cells of skin, epithelial cells of breast, small cell lung carcinoma and seminoma in human: immunohistochemical study on formalin-fixed, paraffin-embedded tissues. Virchows Arch. 1994;424(2):135-41. https://doi.org/10.1007/bf00193492 PMid:7514077

14. Yi ES, Boland JM, Maleszewski JJ, Roden AC, Oliveira AM, Aubry MC, et al. Correlation of IHC and FISH for ALK gene rearrangement in non-small cell lung carcinoma: IHC score 
algorithm for FISH. J Thorac Oncol. 2011;6(3):459-65. https:// doi.org/10.1097/jto.0b013e318209edb9

PMid:21278610

15. Dy GK, Miller AA, Mandrekar SJ, Aubry MC, Langdon RM Jr., Morton RF, et al. A phase II trial of imatinib (ST1571) in patients with c-kit expressing relapsed small-cell lung cancer: A CALGB and NCCTG study. Ann Oncol. 2005;16(11):1811-6. https://doi. org/10.1093/annonc/mdi365

PMid:16087693

16. Zhang YG, Jin ML, Li L, Zhao HY, Zeng $X$, Jiang $L$, et al. Evaluation of ALK rearrangement in Chinese non-small cell lung cancer using FISH, immunohistochemistry, and realtime quantitative RT- PCR on paraffin-embedded tissues. PLoS One. 2013;8(5):e64821. https://doi.org/10.1371/journal. pone. 0064821

PMid:23741400

17. Cabillic F, Gros A, Dugay F, Begueret H, Mesturoux L, Chiforeanu DC, et al. Parallel FISH and immunohistochemical studies of ALK status in 3244 non-small-cell lung cancers reveal major discordances. J Thorac Oncol. 2014;9(3):295-306. https:// doi.org/10.1097/jto.0000000000000072 PMid:24518086

18. Martinez $P$, Hernández-Losa $J$, Montero MÁ, Cedrés $S$, Castellví J, Martinez-Marti $\mathrm{A}$, et al. Fluorescence in situ hybridization and immunohistochemistry as diagnostic methods for ALK positive non-small cell lung cancer patients. PLoS One. 2013;8(1):e52261. https://doi.org/10.1371/journal. pone.0052261 PMid:23359795

19. Park HS, Lee JK, Kim DW, Kulig K, Kim TM, Lee SH, et al. Immunohistochemical screening for anaplastic lymphoma kinase (ALK) rearrangement in advanced non-small cell lung cancer patients. Lung Cancer. 2012;77(2):288-92. https://doi. org/10.1016/j.lungcan.2012.03.004 PMid:22465695

20. Paik JH, Choe G, Kim H, Choe JY, Lee HJ, Lee CT, et al Screening of anaplastic lymphoma kinase rearrangement by immunohistochemistry in non-small cell lung cancer: Correlation with fluorescence in situ hybridization. J Thorac Oncol. 2011;6(3):466-72. https://doi.org/10.1097/ jto.0b013e31820b82e8

PMid:21258247

21. Wallander ML, Geiersbach KB, Tripp SR, Layfield LJ. Comparison of reverse transcription-polymerase chain reaction, immunohistochemistry, and fluorescence in situ hybridization methodologies for detection of echinoderm microtubuleassociated proteinlike 4-anaplastic lymphoma kinase fusionpositive non-small cell lung carcinoma: Implications for optimal clinical testing. Arch Pathol Lab Med. 2012;136(7):796-803. https://doi.org/10.5858/arpa.2011-0321-oa PMid:22742552

22. Alì G, Proietti A, Pelliccioni S, Niccoli C, Lupi C, Sensi E, et al. ALK rearrangement in a large series of consecutive non-small cell lung cancers: Comparison between a new immunohistochemical approach and fluorescence in situ hybridization for the screening of patients eligible for crizotinib treatment. Arch Pathol Lab Med. 2014;138(11):1449-58. https:// doi.org/10.5858/arpa.2013-0388-oa

PMid:24885803

23. Conklin CM, Craddock KJ, Have C, Laskin J, Couture C, lonescu DN. Immunohistochemistry is a reliable screening tool for identification of ALK rearrangement in non-small-cell lung carcinoma and is antibody dependent. J Thorac Oncol. 2013;8(1):45-51. https://doi.org/10.1097/jto.0b013e318274a83e PMid:23196275

24. Selinger Cl, Rogers TM, Russell PA, O'Toole S, Yip P, Wright GM, et al. Testing for ALK rearrangement in lung adenocarcinoma: A multicenter comparison of immunohistochemistry and fluorescent in situ hybridization. Mod Pathol. 2013;26(12):1545-53. https:// doi.org/10.1038/modpathol.2013.87

PMid:23743928

25. To KF, Tong JH, Yeung KS, Lung RW, Law PP, Chau SL, et al. Detection of ALK rearrangement by immunohistochemistry in lung adenocarcinoma and the identification of a novel EML4ALK variant. J Thorac Oncol. 2013;8(7):883-91. https://doi. org/10.1097/jto.0b013e3182904e22 PMid:23625156

26. Zhou J, Zhao J, Sun K, Wang B, Wang L, Chen X, et al. Accurate and economical detection of ALK positive lung adenocarcinoma with semiquantitative immunohistochemical screening. PLoS One. 2014;9(3):e92828. https://doi.org/10.1371/journal. pone.0092828

PMid:24667320

27. Boland JM, Erdogan S, Vasmatzis G, Yang P, Tillmans LS, Johnson MR, et al. Anaplastic lymphoma kinase immunoreactivity correlates with ALK gene rearrangement and transcriptional up-regulation in non-small cell lung carcinomas. Hum Pathol. 2009;40(8):1152-8. https://doi.org/10.1016/j. humpath.2009.01.012 PMid: 19386350

28. Takeuchi K, Choi YL, Togashi Y, Soda M, Hatano S, Inamura K, et al. KIF5B-ALK, a novel fusion oncokinase identified by an immunohistochemistry-based diagnostic system for ALKpositive lung cancer. Clin Cancer Res. 2009;15(9):3143-9. https://doi.org/10.1158/1078-0432.ccr-08-3248 PMid:19383809

29. Jokoji R, Yamasaki T, Minami S, Komuta K, Sakamaki $Y$, Takeuchi $\mathrm{K}$, et al. Combination of morphological feature analysis and immunohistochemistry is useful for screening of EML4-ALK-positive lung adenocarcinoma. J Clin Pathol. 2010;63(12):1066-70. https://doi.org/10.1136/jcp.2010.081166 PMid:20935334

30. Sakai $\mathrm{Y}$, Nakai T, Ohbayashi C, Imagawa N, Yanagita E, Satake R, et al. Immunohistochemical profiling of ALK fusion gene-positive adenocarcinomas of the lung. Int J Surg Pathol. 2013;21(5):476-82. https://doi.org/10.1177/1066896913489345 PMid:23794492

31. Ying J, Guo L, Qiu T, Shan L, Ling Y, Liu X, et al. Diagnostic value of a novel fully automated immunochemistry assay for detection of ALK rearrangement in primary lung adenocarcinoma. Ann Oncol. 2013;24(10):2589-93. https://doi.org/10.1093/annonc/ mdt295 PMid:23904459

32. Han XH, Zhang NN, Ma L, Lin DM, Hao XZ, Liu YT, et al Immunohistochemistry reliably detects ALK rearrangements in patients with advanced non-small-cell lung cancer. Virchows Arch. 2013;463(4):583-91. https://doi.org/10.1007/ s00428-013-1472-7

PMid:23955278

33. Wang J, Cai Y, Dong Y, Nong J, Zhou L, Liu G, et al. Clinical characteristics and outcomes of patients with primary lung adenocarcinoma harboring ALK rearrangements detected by FISH, IHC, and RT-PCR. PLoS One. 2014;9(7):e101551. https://doi.org/10.1371/journal.pone.0101551 PMid:24992725

34. McLeer-Florin A, Moro-Sibilot D, Melis A, Salameire D, Lefebvre C, Ceccaldi $\mathrm{F}$, et al. Dual IHC and FISH testing for ALK gene rearrangement in lung adenocarcinomas in a routine practice: A French study. J Thorac Oncol. 2012;7(2):348-54 https://doi.org/10.1097/jto.0b013e3182381535

PMid:22071784 
35. Govindan R, Page N, Morgensztern D, Read W, Tierney R, Vlahiotis $A$, et al. Changing epidemiology of small-cell lung cancer in the United States over the last 30 years: Analysis of the surveillance, epidemiologic, and end results database. J Clin Oncol. 2006;24(28):4539-44. https://doi.org/10.1200/ jco.2005.04.4859

PMid: 17008692

36. Xuan H, Jingshu G, Fang Y, Na L, Xiaolin S, Zhaoyang Y, et al. Somatic mutation of KIT is rare in small cell lung cancer patients from Northeast China. Histol Histopathol. 2014;29(2):273-8. PMid:23965952

37. Naeem M, Dahiya M, Clark JI, Creech SD, Alkan S. Analysis of c-kit protein expression in small-cell lung carcinoma and its implication for prognosis. Hum Pathol. 2002;33(12):1182-7. https://doi.org/10.1053/hupa.2002.129199

PMid:12514786

38. Burger H, den Bakker MA, Stoter G, Verweij J, Nooter K. Lack of c-kit exon 11 activating mutations in C-KIT/CD117-positive SCLC tumour specimens. Eur J Cancer. 2003;39(6):793-9. https://doi.org/10.1016/s0959-8049(03)00026-1

PMid:12651205

39. Micke $P$, Basrai $M$, Faldum $A$, Bittinger $F$, Rönnstrand $L$, Blaukat $A$, et al. Characterization of c-kit expression in small cell lung cancer: Prognostic and therapeutic implications. Clin
Cancer Res. 2003;9(1):188-94.

PMid: 12538468

40. Rossi G, Cavazza A, Marchioni A, Migaldi M, Bavieri M, Facciolongo N, et al. Kit expression in small cell carcinomas of the lung: effects of chemotherapy. Mod Pathol. 2003;16(10):1041-7. https://doi.org/10.1097/01.mp.0000089780.30006.de PMid:14559988

41. Rohr UP, Rehfeld N, Pflugfelder L, Geddert H, Müller W, Steidl U, et al. Expression of the tyrosine kinase c-kit is an independent prognostic factor in patients with small cell lung cancer. Int $J$ Cancer. 2004;111(2):259-63. https://doi.org/10.1002/ijc.20252 PMid: 15197780

42. Camps C, Sirera R, Bremnes RM, Garde J, Safont MJ, Blasco A, et al. Analysis of c-kit expression in small cell lung cancer: Prevalence and prognostic implications. Lung Cancer. 2006;52(3):343-7. https://doi.org/10.1016/j. lungcan.2006.02.003

PMid: 16574270

43. López-Martin A, Ballestín C, Garcia-Carbonero R, Castaño A Lopez-Ríos F, López-Encuentra A, et al. Prognostic value of KIT expression in small cell lung cancer. Lung Cancer. 2007;56(3):405-13. https://doi.org/10.1016/j. lungcan.2007.01.029

PMid: 17420067 